Received: 19.02.2014.

Professional article

UDK: 376-057.875:17.026.2

\title{
MORAL ABOVE JURISTIC NORMS IN RELATION TO STUDENTS WITH SPECIAL NEEDS
}

\author{
Miroslava Kojić, M.A \\ Preschool teacher training college, Kikinda \\ kojicmb@gmail.com \\ Dragana Stojanović, M.A \\ Preschool teacher training college, Kikinda \\ ddstojanovic@yahoo.com \\ Zagorka Markov, PhD \\ Preschool teacher training college, Kikinda \\ zaga60@beotel.net
}

\begin{abstract}
Authors of this work attempted to accentuate the importance of moral behavior towards the students with disabilities during their studies. Contemporary pedagogic tendency allows students to choose the way they would behave in every day situations that require moral attitude, so in that relation the student becomes an active subject, a potential carrier of emancipatory attitudes and standards in behaving towards his fellow students which happened to have some kind of disability. Using actual examples from real situations and having in mind the importance of the intertwining of broad social categories, identities and dynamic involved (gender, class, age, etc), the authors attempt to prove that students with disabilities can accept the difference of human beings as common and positive thing if helped by fellow students and teachers despite the general thought present in actual society they live in and despite of reflections of bad socio-economic conditions.
\end{abstract}

Keywords: students with disabilities, morality, active attitude, difference. 


\section{INTRODUCTION}

"The erosion of morality" and "descent of social values" are phrases that confront us every now and then for a couple of decades now and we got used to them, which can lead to uncritical, passive accepting of their potential meanings and complexity. They are equally exploited both in media and in every day conversations. One of the open questions is if the rhetoric context of moral behavior is used sincerely to attract attention on something that will leave negative consequences on future generations, or if they are used for daily political demagogic phraseology, which is often the case.

The moral as a term can be defined as searching for the good (which is a broadly constructed term for determinants such as constructive, communicative, pacifistic, understanding, justly) as the highest value, created and enforced both in theoretical concept (constructing the social norms) and in praxis (enacting those norms in actual human behavior). All these aspects are combined in an integrative approach. A general notion of morale can not be defined in substantive/objective but only in formal way. Thus the formal definition is not clear in itself, but is a constituent of wider general as well as sociological concepts of moral and it is related to morality as a social phenomenon. Its essence is to define the morale by specific norms, the characteristics of the internal and external mandatory (with the pricks of conscience as the most distinctive moral sanction and control exercised by the formal society), and in consideration of morality as a social process (actions of people associated with moral norms). The basic types of social processes that establish and reinforce moral standards can be find in the field of education (institutional or noninstitutional) (Marjanović, 2012, 55).

We assume that the previously mentioned phrases ("the erosion of morality" and "descent of social values"), realized rhetorically or pragmatically, negatively affect citizens, especially people with disabilities. Although the current European flows demand of our society to get rid of social preconceptions and insensitiveness, and to pay more attention to people with disabilities, the problem is that the general moral erosion, in the way it is defined, is easily related to Machiavellian aspirations which unequally discriminate in favor of privileged layers of society, therefore without much moral behavior which is exactly what the society is claiming to search for. That could be one of the main reasons for inability to solve problems of people with disabilities in our society. We live in the era of transition and a serious economic crisis, therefore we assume that moral behavior, as defined, should be abetted; as Lukić (Lukić, 1982) writes, morality has to have priority, and in some cases it has to have priority over juristic.

\section{MORALITY AND MORAL DETERMINANTS}

Contemporary pedagogical trends allow the child to choose how to behave in everyday ethical situations. The child becomes an active subject of the everyday intensifying of emancipatory attitude in pedagogical situations which also include his age-fellows who are happened to be disabled in any way (Markov, 2010, 141). Almost four centuries 
ago, Komenski gave advice how to educate morality and virtues to youth. This can be achieved if the right means are used, and they are: constant example of virtue and good morality, beforehand and careful instruction and moderate discipline (Komenski, 1946). It seems that behaving is related to the performing by the given model, so that could also be one of the keys for reinforcing the desired values in the society we live in, starting from the preschool education. Some of the activities that would contribute to the development of social behavior and moral development of the children of preschool-age in this context would be basic comprehension of good and bad on the examples from literature, life, from pictures, related to events in a group and dilemma about what is to be done in a particular case (Mirić, 1995).

Marković (Marković, 2008) sees globalization as a complex social process which influents all segments of life, moral education as well. In that context we should consider the need for moral norm discussion and application in globalization circumstances. Mirić (Mirić, 2008) gives a short historical insight in genesis of development of moral thinking as part of psychology. He overviews the possible classification of special groups and problems related to the research. He does not only point out the elaborated problems such as evaluative moral judgment and thinking, differentiating moral and non-moral rules and norms and neglecting categories such as comprehending moral situations, but also to the problems which psychologists did not recognize as problems related to the researches. These problems are development of moral terminology, the meaning of moral words, etc. Stojanović (Stojanović, 2008) assumes that methodological procedures, so far, were not successful in beholding dynamics and process of moral education and, that therefore, it should be analysed to search for alternative approaches and algorithms. The author also suggests further actions of qualitative collating data which are used in moral education study: qualitative analyses of the phenomenon, objective hermeneutics, discourse analyses, etc. Petričković (Petričković, 2008) mentions that contemporary science of social work has not succeeded to adequatly solve the basic items of very complex moral problems from consistent-epistemiological point of view. Minimal ethic cognition based on philosophic grounds enables establishing seria of partially explained entities in the field. The author intercedes futuristic science of social work opposed to the contemporary one which will philosophically be the focus of ehtics. Ranđelović (Ranđelović, 2002) analyzes moral education in pedagogic creativity of Serbia from 1900 to 1941 and mentions characteristics of Bakić creativity in this field. One of the features of Bakić creativity in moral education is expressed in his sense as the project of social eligible relation of a person towards his society making the value hyerarchy in the process of education and moral issues. According to many, moral basis is in human specific capability to understand a world around him/her and to act in a specific, socially valued and constructive way. This capability is comprehended and named differently. Some of the names are: morality, moral sense, moral sentiment; however it is comprehended as an independent human capability, or as a feature which derives from its other specific characteristic of his sociability (Lukić, 1982). We can start from Freud's studies about morality development, because it immensely influented most of contemporary theories about morality development. Freud concluded, on the bases of his researches, that agressive and sexual 
impulses are innate and actuators of people's activities. Being delivered, a child is in this sense amoral and it tends to satisfy its personal impulses. Parents (and society in which parental figures are immersed) limit child's impulses and the crucial moment, according to Freud, for morality development is at the age of five, when Oedipus complex is ceased and the child identifies himself with the basic gender identity and norms which the society leads him/her into, and which the parental figures represent. Super-ego is formed at this time. It overtakes the behavior control from child's parents/parental figures. Super-ego is thus formed following the parental (and in the same time, society-dictated) model. This enables transfering traditional cultural values from generation to generation. Super-ego, at child's age of approximately five, performs the functions of self-observation and concience and punishes for inadmissible thoughts in the form of a guilt feeling (Freud, 1973). Cognitive development approach excel in approach to morality as to a series of qualitatively different stadia of thinking. This approach focuses on cognitive processes (Saltzstein, 1983). Jevtić (Jevtić, 2008) assumes that basic theoretic assumptions of cognitive development approach, morality and the methods used in educational practice are useful for analyses of abetment method, and partially for restraint method in moral forming among children and youth. The author concludes, on the bases of different comprehending she encounters in pedagogic literature, that the authors most frequently set off four methods of moral education: persuasion method (assuring), habituation method (practicing), abetment method and punishment method (restraining). They are used for realization of educational aims that strive to make children internalize knowledge, rules and values through modification of adult behavior, through explicit study, awards and punishments. Popović (Popović, 1977) maintains that all human beings stick to certain interhuman rules for which it is said that arise from the need to set limits to behavior to obtain most convenient conditions for collective life. Kamenov (Kamenov, 2006) understands morality as a set of intercourse regulations which is to acquire something that is conceptualized as a general wellfare, because it is the stipulation for human existance survival. Morality is transferred to children from the moment they start to feel as members of their society. The morality standards are in this sense intertwined with society standard or, rather, they are a society standard itself. So the process of internalizing morality is most closely related to the processes of socialization.

Our time, no matter how modern and liberal it seems, still raises the questions of stereotyping and inequality which is seen particularly in the field of gender identities and relations. The 21 st century actively reinforces the need for gender equality standard, the idea that achieved in feminist writings and actions from 19th century (even earlier!), all through 20th century until today (Gamble, 2006). It seems that, despite all the educational and institutional programs that encourage gaining knowledge in gender equality field women advance slowly in the business world, they are still paid less than their male counterparts and they need more time and effort to reach the desired positions. In business, especially a global one, women in high positions are very rare. The prejudice is that women are not "cast" for leadership, that they are too emotional, and that they lack the power and this is still the prevalent model that is offered to the children that are supposed to internalize their gender roles in the particular society they live in. The aim of this 
paper is also to suggest focusing on the category of gender as an important category in thinking through the concepts of contemporary society norms in discussing the aspect of juridical and moral in the situation of cultural and ability diverse social context we live in. In the other words, the strategies of educating (children or students) should in the same time give directions of how to use cultural policy in removing barriers for managing and establishing gender equality (Jurišić, Vrcelj, 2013, 299).

\section{ATTITUDE TOWARDS PEOPLE WITH SPECIAL NEEDS IN EUROPEAN COUNTRIES}

The last years of the twentieth century brought immence changes in relations towards children with special needs from whom some are with partial, and some are with permanent capability damages. Isolation and segregation have been suppressed by rehabilitation which are using new technologies and specific methods to encourage the development of the rest of the capabilities and therefore replace or alleviate the lack of sight, hearing or some other function. In seventeen European countries accent is on the aim of early intervention, i.e. damage prevention, early diagnoses and intervention which mostly block the damage and stimulates the child and his capabilities as much as possible.

Social position of disabled people is defined by Law in Serbia, together with numerous legal provisions and regulations. Therefore, disabled people rights are covered by all important laws, voted by the Parliament. Almost every legal provision includes certain right of disabled people, in at least one of its acts. Disabled people position is regulated by International Convention which is accepted by The Republic of Serbia and became part of its internal legislature and valid as the Law voted by the Parliament. The most important acts of international rights are: UN Declaration on the Rights of Disabled Persons, Convention on the Rights of Disabled Persons, Convention on the Rights of a Child, and soon to come Convention on the Protection and Provotion of the Rights and Dignity of Disabled Persons.

In the last few years Serbia made significant steps in convergence of its legislature towards European Union standards. Many legal rules are made to regulate the protection of disabled people rights and provide the improvement of their position in contemporary society. When we deal with education of children with developmental difficulties or disabled ones, there are three legal acts covering this field: Law on preschool education (Službeni glasnik Republike Srbije, 18/10) ${ }^{1}$, Law on basic system education (Sl. glasnik $1 \quad$ In the text it will be reffered as ZPVO (shortened from Zakon o predškolskom vaspitanju i obrazovanju). The first of the principles of pre-school education guarantees equal rights and accessability of all forms of pre-school education, without discrimination and selecting on the grounds of sex, social, cultural, ethnic, religious or other affiliation, residental area, material or health condition, developmental difficulties or disabilities, as also other grounds, according to the regulation (part 4 section $2 \mathrm{ZPVO}$ ). Legislature regulates pre-school programs, their development and creating individual approach in realization of educational work to provide additional support to children, especially those with developmental difficulties, the ones on hospital care, children from socially, economically or in the other way handicapped surroundings who are in their educational groups, with respect of their developmental, educational, health and socio-cultural needs (part 16 section 5 ZPVO). Educational institution organizes work with children in educational group 


\author{
RS, 72/09) $)^{2}$ and Law on prevention discrimination of disabled persons (Sl. glasnik RS, \\ $33 / 06)^{3}$.
}

which number of members differ according to their age. To obtain most qualitative work with disabled children, regulations restict the number of children attending the developmental group from four to six (part 30 section 5 ZPVO). Part 34 of this law regulates work organization with children with developmental difficulties. They use their right on pre-school education in a group, and with additional support and an individual educational plan made in concordance with the Law. The pre-school institution which enrolles the child with developmental difficulties estimates the need for obtaining additional educational, medical and social support and asks the chosen doctor and the local interdepartment board to estimate the need in question and to obtain the support in all mentioned ways. An educational group cannot have more than two children with developmental disabilities. The educational group that enrolled one child with special needs will enroll three less of non-disabled ones refering to the Law. Children with developmental disabilities can join the educational group during the enrollment process. During the educational process those children are monitored and on the bases of pedagogic board and the expert team for inclusive education, the child with developmental disabilities can be transferred from resource room to educational group according to the Law. Specific condition estimates for the need for obtaining additional educational, medical and social support, members and methods of interdepartment boards are regulated among ministers of health, social politics and education (part $34 \mathrm{ZPVO}$ ).

2 It will be reffered as ZOSOV (Zakon o osnovama sistema obrazovanja i vaspitanja). One of the basic principles of our educational system guarantees equal rights and accessability of all forms of education, without discrimination and selecting on the grounds of sex, social, cultural, ethnic, religious or other affiliation, residental area, material or health condition, developmental difficulties or disabilities, as also other grounds (part 3 section $1 \mathrm{ZOSOV}$ ). In practicing the principles, special attantion is paid, among the rest, to the opportunity for children, students and adults with developmental difficulties and disabilities, regardless of their own material conditions have acces to all levels of education in respective institutions, while the ones in the institutions of social care, ill children and students realize the right on education while there and during their stay in hospital or house recovery period (part 3 section 3 ). Regulations which guarantee the right on inclusive education are present in part 6 of this Law, in which is assumed that persons with developmental difficulties and disabilities have the right on education which would respect their educational needs in mainstream institutions of the system with individual and group.

3 Law on preventing discriminations of persons with disabilities, in use from 1 January 2007, regulate the general method of non-discrimination on the bases of disability, special cases of discriminations towards persons with disabilities, norms of protection of persons exposed to discrinimation and the acts taken to abet equality and social inferrence of persons with disabilities for his disability. Discrimination on the bases of disability is forbidden on all the levels of education. Discriminationation covers the following: 1 refusing admission of a pre-school child, pupil or a student with disabilities to an educational institution which suits his previously gained knoledge, i.e. educational capabilities; 2 expelling a pre-school child, pupil or a student with disabilities from the educational institution he already attends for the reasons connected with his disabilities; 3 excluding having disabilities as the special condition for admission to the institution, except if the preliminary psycho-phisical capabilities tests are accorded to the regulations of that field of education (part 18 section 2). Discrimination in education do not cover the following: 1 preliminary testing certain aptitudes of pre-school children, pupils, students or candidates on enrollment in an educational institution for a certain subject of group of subjects, of their artistic inclinations or other special talent; 2 organizing special methods of education for pre-school children who are intellectually incapable to follow the regular educational agenda, as to transfer them to special educational work if the enrollment is done according to the regulations of the institution and allows asessment of the need and performing the kind of education of pre-school children and pupils (part 19). Disturbing, insulting and scorning of a pre-school child, pupil or a student with disabilities for his disability, when those are performed by teachers or others employed in the educational institution (part 20) is heavy mode of discrimination. 


\section{HUMAN SUPPORT AND RELATION TOWARDS PEOPLE WITH DISABILITIES ON FACULTIES THEY ATTEND}

General rule is to obtain all students (including the students with some kind of disability) optimal conditions to enable them devote completely to their studies and the activities which acompany the studies. The following strategies include these principles: 1. Faculty is obliged to obtain its students quality and safe access to every building (ramps, balustrades, elevators, etc.);

2. It is necessary to organize additional education for the students with specific development to show that beauty of the diverse society lies in supporting additional programs in special pre-school group or school according to this. The Law also enables educational work for persons who use sign language, special alpabet or other technical gadgets in educational process. In the school which they attend, principal should form an expert team for inclusive education (part 66 ZOSOV). The Law prescribes the norms concerning educational programs. Primary and high schools can but still are not obligated to realize individual educational plans for students and adults with disabilities (part 69 ZOSOV). Educational programs of primary and high school education contain suggestions for its creation for students who need additional educational support (part 74 ZOSOV). Children and students with developmental difficulties or disabilities need additional education support and are to be obtained with it by the institution. It removes physical and communicational obstacles and creates an individual educational plan tailored to the needs of particular child/student (part 77 ZOSOV). Parts 82-85 of the Law contain regulate the method of taking the final examination in primary and high schools. Students with developmental difficulties or disabilities take the final examination according to their motility disturbances and sense capabilities, i.e. conditions demanded by the type of disability, so they can be released from a part of the final examination from the subject in which the standards of achievements were adjusted for them. Legislature prescribed the necessity to edit books with adjusted programe for realization of educational work with students with developmental difficulties or disabilities respective to their needs (part 102 ZOSOV). Educational institution can enable children or students with developmental difficulties or disabilities the presence of their escort during educational work (part 117 ZOSOV). Law on preventing discriminations of persons with disabilities, in use from 1 January 2007, regulate the general method of non-discrimination on the bases of disability, special cases of discriminations towards persons with disabilities, norms of protection of persons exposed to discrinimation and the acts taken to abet equality and social inferrence of persons with disabilities for his disability. Discrimination on the bases of disability is forbidden on all the levels of education. Discrimination covers the following: a) refusing admission of a pre-school child, pupil or a student with disabilities to an educational institution which suits his previously gained knoledge, i.e. educational capabilities;

b) expelling a pre-school child, pupil or a student with disabilities from the educational institution he already attends for the reasons connected with his disabilities;

c) excluding having disabilities as the special condition for admission to the institution, 
except if the preliminary psycho-phisical capabilities tests are accorded to the regulations of that field of education (part 18 section 2).

Discrimination in education do not cover the following:

a) preliminary testing certain aptitudes of pre-school children, pupils, students or candidates on enrollment in an educational institution for a certain subject of group of subjects, of their artistic inclinations or other special talent;

b) organizing special methods of education for pre-school children who are intellectually incapable to follow the regular educational agenda, as to transfer them to special educational work if the enrollment is done according to the regulations of the institution and allows asessment of the need and performing the kind of education of pre-school children and pupils (part 19). Disturbing, insulting and scorning of a pre-school child, pupil or a student with disabilities for his disability, when those are performed by teachers or others employed in the educational institution (part 20) is heavy mode of discrimination. 3. To help a student with disability cope in the enviroment, and undergo adaptive and accidental crisis it is necessary to direct him to pro-socially oriented students, or ask them to explain how the faculty or college functions, or what is to pay attention to, during the first few days;

4. If a student gets into serious accidental crisis he should be invited on sincere talk to be explained that the crisis happens to most of the students. The talk should be guided by someone who is experienced in work with students with disabilities in similar situations and who succeeded in preserving students, obtaining possibility to finish their studies in optimal conditions;

5. It is very important to make students notice that more education they get, the easier they will find future job and that sooner or later they will have to become independent for their future;

6. If a student outstands in a talent, he should be supported;

7. Outstanding student should be sent to competitions where his confidence would grow; 8. The students should be praised on teachers' meetings, and his success should be edited in students' newspapers, on notice boards, in annual reports, etc;

9. If a student lives in the dormitory he should be sharing it with pro-social oriented student or students, who will much earlier recognize his qualities and accept his routine; 10. The student should never feel undesirable for his disability. On the contrary, he should be encouraged to feel to belong to his peer group. He should be sharing both successful and failing results and overcome them as easy as possible respectively to the situation;

11. Special role in the first few months of adaptation should be also taken by professors who would, by their attitude, contribute in making students with disabilities feel welcome in the new enviroment, emphasising their courage to decide on the move;

12. The student, during the first few months, gains best friends and they are one of the means that will encourage him stay on the studies;

13. Students should organize public discussions to talk openly about problems of the students with disabilities and to obviously support them, for the sole decision to leave the safety of parental home what presents courage and challenge by itself;

14. The student should be acquainted with the fact that European integration implies 
more students with disabilities on private faculties, among all. This peer approach enables the students with disabilities to accept their divesity and develop freely to the pitch of their capabilities. However, mass population students accept diversity of their peers in human manner. At the same time we emphasise the difference among students when motivation, confidence, self-respect and intention to finish studies is in question. We assume that, in the spheres, there are no differences, and that sometimes the disabilities can be intense stimulus for the student prove bio-psycho-social potentials.

\section{EXAMPLES FROM THE PRACTICE}

The case studies presented here are the result of the conversations and interviews the authors made with the students of the various State universities and colleges in The Republic of Serbia at the series of panel discussions on the issues of the education and disability problems in children and adults. These panel discussions were organized by the Preschool Teacher Training College in Kikinda, and they are being held every year since 2004. The following case studies depict the specific situations of the students that have been studying in the time period between 2000 and 2013.

Example 1 - Student I. T. was born as well developing and healthy baby. According to his parents' words, he strarted loosing hearing after a vaccine. The period up to beginning of his studies went relatively easy for this student. However, leaving for Belgrade on studies, despite having intellectual capabilities above average, did not result with coping with the new enviroment. Due to the fact that at the time inclusion was almost completely unheard of, the young man was on his own, and after a number of oppressions he went back home, but eventually he enrolled a college, and then a faculty in his hometown. He claims that empathic professors and peers were of much help. They helped him do the tasks, but in following the lectures most. He was never feeling depressed for his disabilities. He overcame his crisis easier than most of his peers. Today he works as regular employee. He is not on the post he studied for, he is expecting one, but he is affirmed in his environment. The job he does demands much intellectual and physical efforts, but according to the words of his superiors, he is claimed to be one of the best employees.

Example 2 Student B. T. was also born as healthy and well developing baby, but etiology of hearing impairment was never completely clarified. This student was never burdened by it. He attended regular kindergarten and school. He was outstanding pupil, also interested in sports. After graduating, he enrolled technology studies and finished it on time. He did not have major problems during his studies. Although trying hard to remember extremely hard situation for him during the studies, he could not. It seems to him that professors were not differentiating him from the other students. He finished his studies with high average percentage, but he assumes that this was earned by his work only. His outstanding sport results achieved on the faculty made him his colleagues' and professors' favourite. In the meantime, due to his talent, he was abroad and practiced sport professionally. His employer gave him temporary leave, but he welcomed him back 
impatiently.

Example 3 - Student L. K. grew up in multitudinous family. She was the only female child. She was physically and mentally abused by her father. Neither her mother nor brothers could help her. During the lectures the girl was sad and it was obvious that something bothered her. This girl's bio-socio-emotional problem was obvious. The level of her self-respect and confidence was on the bottom level of tolerance. During the practices she could not expose her attitude and fight for it. Sympathetic behavior of her peers and random brief statement implied that she had a problem. Her professor talked to her and what she assumed was correct. The student was a victim of familiar abuse and gender discrimination. She cried and asked not to spread this. She had to stay at her friends' very often for few days and to learn and take her exams under ultimate stress. Respecting her wish, and at the same time moral and professional duty to do something to protect her from being abused, the professor had to do something. While trying to find the best solution, and intending to protect the girl from being emotionally and physically abused, the girl left her parental house. She started living with her boyfriend who she dated for some time. Professor's fear that that could be a mistake, fortunatelly did not realize. Soon the girl started a family and had two children. She lives and works in an other town; away from insecure and socio-emotionally unstable surrounding, she became stronger and more confident person. Her socio-emotional depression is still obvious. She reluctantly comes to her birthplace. She is bonded to several relatives and colleagues who did not let her down neither in worst situations.

Example 4 - Student S. C, absolutely blind, after attending high school enrolles Teachers college - instrument department. He expresses extraordinary talent. He did not attend a kindergarten, but was enrolled, at the age of nine, in the Special school for blind and poor sighted pupils Veljko Radovanović in Zemun. He outshines separation from his mother as worst moment in his life. However, he gains his peers benevolence and copes with school happenings. He finished Teacher college on time with high average percentage. In the meanwhile he got married and got a son. With the help of his wife, who was beside him (and she was sighted), he got the needed books and enrolled the third year in Belgrade. He was obtaining the books in Braille reading codes from abroad. His wife was reading and recording the theoritic bases. Very soon, this teacher became a professor with very successful career. He emphasizes humanness and empathy of his colleagues from the studies, professors, assistants and all of those who contributed in completing his studies, and afterwards affirm in his profession. His wife's role is immeasurable. She standed as his full support and organized her life according to the needs of her husband and son by her own will creating harmonious and succesful family life in which every family member could achieve his/her best.

Example 5 Student N. A, due to his above average intellectual capabilities, realized from his early age that he differed from the others. He has cerebral palsy. With persistence of his mother and numerous surgical interventions, he began walking. Beginning of his faculty studies was an adaptive crises. He gained many friends and spend wonderful moments in learning and fun. Their pro-sociality and empathy exposed only at the time when, as the others, he had regular crisis. In the meantime it was noticed 
that he owned talents: for music, painting, writing, interpersonal intelligence, etc. It is important to emphasize that his mother's intervention and persistance made him enroll into a regular kindergarten, school and studies. He finished psychology studies with high marks. He got a job, but his director made this young man enroll post-diploma studies and head a different way. Today, this affirmed psychologist along helping children, adollescents and elder citizens, writes books, does charity work, etc. He achieved homeostasis between environmental and his inner life.

Example 6 Student D. I. was an adopted child. Her stepparents accepted her as their own, but some day the girl found out the truth - that she did not live in her biological family. Long kept truth from her and her leaving on studies made mess in her head. She seeked for answers on many questions. She became problematic. Her father died in the meantime. She took her stepfather's death very tough. Her stepmother helped her find her biological mother. She was disappointed. After loosing a year, this student came back with much renunciation, but she succeeded stabilize herself. Most helpful were, beside her stepmother, colleagues and professors.

Unfortunately, these are only some of the students who, due to positive emotional environment and support, succeeded to rise above the situation and overcome their problems which made them stigmatized in the community they lived in. Many never succedded, due to the nonsupporting environment.

Example 7 Student I.V. was on her third year of studying. She was known for her cheerfulness and openness. But the rest of the students started noticing the changes in her behavior. She became uncomunicative and emotionally unstable. She is often late for classes which was not the case in the first and second year of her studying. In one moments she decided to comt to the college with her mother and to seek help and understanding from the school for she became the victim of the violent behavior of her boyfriend. With the string support of the family, colleagues from her studies (especially heer peer female colleagues) and the professors, and certainly with the help of the police she succeeded in gaining back her freedom. She became very active in the additional school educational activities that were dedicated to the violence issue, analyzing both her past situation and using the knowledge she gained on the issues of recognizing the potential abuser and getting rid of him, accentuating the importance of early recognizing of the situation which could possibly lead to the abuse. She stressed the importance of education and knowledge in young women's lives. After this traumatic experience she succesfully finished her studies and moved on with her life.

Example 8 Student T. K. was born out of an extramarital relation of the problematic mother who often left her alone in the house while she was just a small child. She was neglected and abused. She had many problems with speech and communication. She was messy and malnourished. In her psychosomatic development she was significantly behind her generation. Center for social care separated her from her mother and gave her to the foster family, but that family also didn't care properly about her, so he was given to the older couple who didn't have children of their own. This couple gave her selfless love and care and became her first real family. Growing up with them, the girl gained self-confidence and became educated and well-behaved child. After finished high school 
she enrolled the college and she is currently in the finishing year of studying. She is an excellent student and she doesn't hide her attachment to their foster parents stating that it is solely because of them that she became a succesful person with a very meaningful life.

\section{CONCLUSION}

Bad material situation can be a reason for bad material and techique conditions in kindergartens, schools and faculties. However, emploees in educational process cannot seek for an excuse for their possible unprofessional behaviour. A teacher without moral qualities, which means without the striving for creating an atmosphere of mutual understandance and peer support leaves the worst consequences on the generations of students. Teachers fully participate in forming and enforcing of moral norms in the society, so the concequences of their behavior are dramatic and grow even bigger by the time. Yet, there are moral, pro-socially oriented, altruistic and tollerant teachers and professors. They, irrespectively to bad material conditions, in the choice between active and inactive, interested or uninterested, supporting or not supporting always choose the former. They do not need juristic imperative acts to perform special humanistic programs towards the children with special needs. We must not minimize the factor of natural environment of the student - faculty, with colleagues which should be educated, motivated and supported to heartily do all they can to help their friends with disabilities to realize their potentials. However, despite of all the progressive acts and standards of today, our society is still burdened with prejudices and the students still meet with the nonunderstanding and opressive attitudes of individuals and groups in the society they live in.

Moral behavior of the student's environment is above all the legislature, and it should not be waited for the legislature procedure to start applying the numerous techniques for creating the atmosphere of the same chances for an individual development, for peer communication and mutual understanding. So acting towards the chosen standard would be crucial - everything depends on the fact if it is used as sheer rethorics or as inseparable part of our reality. We already have the capacity of making the society more just and more adjusted to its richly diverse structure, whether these differences lay in the ability level, or in gender or class cathegory, or in anything else. One of the keys to achieve all this is in the system of education (both parental and institutional) - so we are all equally responsible.

\section{BIBLIOGRAPHY}

1. Frojd, S. (1973). Nova predavanja za uvodjenje u psihoanalizu (Odabrana dela, knj.8.). Novi Sad: Matica Srpska.

2. Gamble, Sarah. (2006). The Routledge Companion to Feminism and Postfeminism. London, New York: Routledge, Taylor \& Francis Group.

3. Jevtić, B. (2008). Actual views of method of encouragement and prevention in moral 
pedagogical work. Pedagogija, 63 (4), 580-588.

4. Jurišić, A.,\& Vrcelj, N. (2013). The cultural policy of gender equality the role of women in global business. Kultura, 138, 299-314.

5. Kamenov, E. (1995). Model osnova programa vaspitno-obrazovnog rada sa predškolskom decom. Novi Sad i Kikinda: Filozofski fakultet iViša škola za obrazovanje.

6. Kamenov, E. (1997). Metodika - Metodička uputstva za Model B. Osnova programa predškolskog vaspitanja i obrazovanja dece od tri do sedam godina. Novi Sad: Odsek za pedagogiju Filozofskog fakulteta u Novom Sadu, Republička Zajednica viših škola za obrazovanje vaspitača.

7. Kamenov, E. (2006). Vaspitno-obrazovni rad u dečijem vrtiću. Novi Sad: Dragon.

8. Komenski, J, A. (1946). Materinska škola. Beograd: Prosveta državno izdavačko preduzeće Srbije.

9. Lukić, R. (1982). Sociologija morala. Beograd: Naučna knjiga.

10. 1Markov, Z. (2010). Ethical behaviour towards children having special needs. Socijalna misao,17(3), 141-154.

11. Marjanović, M.(2012). Sociological concept of morale. Zbornik radova Pravnog fakulteta, Novi Sad, 46(4), 55-67.

12. Marković, D. Ž. (2008). Globalizacija i visokokškolsko obrazovanje. Niš: Državni Univerzitet Novi Pazar .

13. Ministarstvo rada, zapošljavanja i socijalne politike (2004). Vodič kroz prava osoba sa invaliditetom u Republici Srbiji. Beograd: Sektor za zaštitu osoba sa posebnim potrebama.

14. Petričković, M. (2008). Primer of ethical ideas: Futuristic issue of contemporary science of social work. Socijalna misao, 15 (2), 61-84.

15. Popović, B. (1977). Uvod u psihologiju morala. Beograd: Naučna knjiga.

16. Ranđelović, J. (2002). The ehical education in Serbian pedagogy between 1900-1941. Teme, 26 (3), 42-444.

17. Saltzstein, D. H. (1983). Critical issues in Kohlberg s theory of moral reasoning. Monographs of Society for Research in Child Development, 48 (1-2), 108-119.

18. Stojanović, A. (2008). Alternative methodological approach and procedures in moral education. Pedagoška stvarnost, 54 (3-4), 200-218.

19. Volter (1990). Filozofski rečnik. Novi Sad: Matica srpska.

20. Zakon o predškolskom vaspitanju i obrazovanju, Službeni glasnik RS, 18/10 od 26 . 3. 2010.

21. Zakon o osnovama sistema obrazovanja i vasptanja, Sl. glasnik RS, 72/09, od 31. 08. 2009.

22. Zakon o sprečavanju diskriminacije osoba sa invaliditetom, Sl. glasnik RS, 33/06, od 17. 04. 2006. 